\title{
Symbolic Da'wah of Cultural Acculturation of Muhammad Cheng Hoo Mosque Purbalingga
}

\author{
M. Wahyu Fauzi Aziz ${ }^{1 *}$, Musmuallim², M. Happy Nur Tsani ${ }^{3}$ \\ ${ }^{1}$ Universitas Islam Negeri Prof. K.H. Saifuddin Zuhri Purwokerto \\ ${ }^{2}$ Universitas Jenderal Soedirman Purwokerto \\ ${ }^{3}$ Universitas Nahdlatul Ulama Purwokerto
}

\begin{abstract}
This study examines the symbolic preaching of Chinese Islam at the Muhammad Cheng Hoo Mosque, Purbalingga Regency, Central Java. A place of worship that has become a symbol of a house of worship for Chinese Muslims in particular and Muslims in general. The architecture of the building which is unique, interesting, and similar to that of a temple as a place of worship for the Confucian people is a distinctive feature of the Islamic treasures. Cheng Hoo Purbalingga Mosque has an attraction, from the physical side, it is not so visible as a mosque building, but when you go inside, the nuances of Islam will clearly show the mixture of Chinese cultural acculturation with Islam. This study concludes that the ornaments and shapes of this mosque contain symbolic values and messages (wisdom) of da'wah. The symbolic values of da'wah contained, namely: the value of beauty (artistic), cultural values (turats), accommodative values, brotherhood values (ukhuwah) and the value of unity. The establishment of the Cheng Hoo Mosque gave a message (wisdom) of da'wah that Islam teaches hospitality and openness to all cultural entities, Islam adapts and interacts with various social traditions and Islam teaches tolerance in a life full of diversity.
\end{abstract}

Keywords: Symbolic Da’wah, Mosque, Chinese Islam

\section{Introduction}

The Indonesian nation stands on various ethnic groups, religions, races and customs (SARA) (Choirul Anwar, 2018). A great nation with a variety of diversity that is deeply rooted as a great nation's strength. This diversity is a sign of the power of Allah SWT who wants the life of the universe to be diverse. Moreover, humans are created by nature already in different conditions. So it is important for mankind, especially for Muslims to get to know each other (lita'arafu) with each other who live with nations and tribes (Said Romadlan, 2019). So that the diversity of mankind is absolutely a sunatullah which, like it or not, must be lived, which in the future must be grateful for the faithful.

Being Muslims in Indonesia must be willing, able, accepting and acknowledging the diversity that this nation had long before the archipelago was founded. Diversity or diversity is a valuable space for the wealth of the Indonesian nation. Because lately, religious people in Indonesia, especially Muslims, often clash with each other which has the potential to trigger conflicts between people. We often encounter extreme movements, intolerant acts, truth claims and hate speech using religious authorities, either directly or indirectly, in the mass media or social media.

The diversity of this nation must be maintained and cared for. The inculcation of the value of love among others in the space of difference is carried out through an understanding of respect for inter-religious people. In the context of Islam, planting can be done with an invitation or called the way of da'wah. Inviting others to the path of truth to achieve certain goals becomes a simple definition of da'wah (Safrodin, 2008). Symbolic da'wah describes the importance of the path of da'wah that puts the value of difference (diversity) into one of the people's strengths in the form of symbols that negate the meaning of unity in diversity (unity in diversity).

Polite and peaceful da'wah with good material (positive content) to invite each other to strengthen unity in diversity should be a shared awareness and task. Supported by da'wah which is manifested in religious symbols and in the form of artifacts as a reminder of the importance of the strength of the unity of the ummah even in very complex 
differences. One of them is through the mosque as a religious symbol of Muslims as well as a house of worship that provides comfort and peace for mankind, especially for the Muslims around it.

Muhammad Cheng Hoo Mosque, Purbalingga Regency, Central Java, has become a symbol of Muslim houses of worship, especially in Purbalingga Regency. Its shape is similar to the architectural building of Chinese civilization or better known as a temple building as a place of worship for the Confucians. The combination of China and Islam has become a cultural acculturation as a separate feature for Chinese Muslims who color the treasures of the Islamic world. The Chinese-style mosque became a form of acculturation and a combination of Islamic religious symbols with Chinese architecture.

In Indonesia, mosques with Chinese Islamic architecture or known as pagodas have been built by many Chinese Muslims. Among the Cheng Hoo mosques that have been established are Muhammad Cheng Hoo Mosque Surabaya (2002), Sriwijaya Palembang Cheng Ho Mosque (2006), Muhammad Cheng Hoo Mosque Kutai Kartanegara (2007), Muhammad Cheng Hoo Mosque Purbalingga (2011), Muhammad Cheng Hoo Mosque Gowa (2014), Muhammad Cheng Hoo Mosque Batam (2015), Muhammad Cheng Hoo Mosque Banyuwangi (2016), and other mosques. More often the name of the Cheng Hoo Mosque is added to the first name of Muhammad. The building style of the Cheng Hoo mosque uses a Chinese architectural style that imitates the Niu Jie mosque in Bejing (https://tirto.id/cpDS, 2021).

Muhammad Cheng Hoo Mosque in Selaganggeng, Mrebet, Purbalingga Regency (Cheng Hoo Mosque) was originally built on the initiative of Chinese Islamic leaders and the Indonesian Chinese Islamic Association (PITI) community. PITI's struggle made a positive contribution to the surrounding community, this was marked by inviting the community to participate in the construction of the mosque at the beginning of its establishment. The main purpose of establishing this mosque is to invite people to practice the teachings of the Prophet Muhammad. The establishment of the Cheng Hoo Mosque was inspired by a hadith, seek knowledge as far as China, which provides an understanding of the importance of knowledge to be sought and explored even if it reaches overseas. With the philosophy of China, it contains a myriad of scientific treasures that must be studied and benefit others. The style of the building, which is similar to the temple, is a sign that Islam is diverse and can exist anywhere regardless of ethnicity and ethnicity.

Da'wah that is carried out in daily life at the Cheng Hoo Mosque prioritizes the principle of benefit. When a group of people have provided positive benefits, then this reflects the values of Pancasila, where PITI was founded using the Pancasila as a guideline and principle in the life of the nation and state. Nationalist attitudes are also used as a perspective in a pluralistic life as social capital to fortify diversity. For this reason, Cheng Hoo Mosque continues to carry out polite da'wah inviting to the path of goodness in a good way by not taking sides with certain groups.

Responding to the development of increasingly complex religious attitudes in society, the presence of da'wah that upholds the value of diversity as a national treasure is an option to be developed. So in this context, this research wants to unravel the content or content of the da'wah delivered by the preacher or preacher who was held at the Cheng Hoo Mosque in providing understanding and coolness for the people, especially in realizing religious moderation. In addition, symbolic da'wah also needs to be continuously echoed as an alternative to instrumental fundamentals to provide awareness and maturity through the media of a mosque that symbolizes the Chinese ethnicity.

Symbolic da'wah inspires religious people in knitting brotherhood in religious diversity. Where religion should be an inspiration for the people, not the other way around as an aspiration which sometimes leads to unhealthy competition. The symbol of the Cheng Hoo Mosque is an inspiration for the people to continue to build brotherhood and unity in the midst of plural diversity. This article describes the symbolic meaning, content of da'wah values and symbolic messages (wisdom) that can be continuously explored and broadcast by the Cheng Hoo Mosque so that it becomes a spiritual destination that symbolizes the diversity of religious life. 


\section{Research Methods}

This research is a field research with descriptive qualitative type. To explore and obtain data, the research methods used include in-depth interviews, participatory observation, and document studies. The data search method is carried out by snowballing from one source to another to obtain the authenticity of the supporting information.

In-depth interviews were used to explore information and experiences carried out by the informants. In this case, the interviewee was the Founder and Initiator of the Muhammad Cheng Hoo Purbalingga Mosque, Chairman of the Purbalingga Chinese Islamic Association. Manager of Takmir Mosque Muhammad Cheng Hoo Purbalingga. Meanwhile, participatory observations were carried out to be directly involved with the activities and experiences of PITI Purbalingga in carrying out its various da'wah.

Data collection techniques through the method of documentation, interviews and observations. The documentation method is carried out to find evidence of documents or supporting literature to fulfill information related to the history, construction and management of the Cheng Hoo Mosque. The interview method was used to seek information from sources including mosque founders, PITI Purbalingga administrators, stakeholders, local religious (Islamic) leaders, community leaders, youth leaders and leaders of relevant and competent community organizations.

Observations were made to conduct direct observations at the Cheng Hoo Mosque and the Purbalingga PITI Secretariat to find out and obtain data regarding the existence, programs and activities carried out. The data obtained were arranged systematically and presented descriptively and elaborated with data from various literature reviews to support the analysis.

\section{Research Results And Discussion Mosques as Da'wah Centers}

Da'wah mentioned by Mahfud (1970) is normatively defined as inviting people to the path of goodness and guidance to obtain happiness in the world and the hereafter. In da'wah, the elements of da'wah include da'i, mad'u, methods, materials and media. A preacher is required to be able to convey material clearly and can be accepted by mad'u. Because a preacher is considered successful if he has been able to provide understanding to his mad'u. For example, by using the bil wisdom method, da'wah is carried out in a wise and wise way, namely through an approach to the object of da'wah so that they are able to carry out da'wah of their own accord, without coercion, pressure or conflict.

Da'wah that upholds the value of diversity needs to present a study of intercultural da'wah. According to Aripudin (2012) intercultural da'wah has several scopes of study of da'wah science, namely, including: (1) Studying the basics of the symbolic interaction of da'i with mad'u who have different cultural backgrounds in the course of da'wah. i; (2) Examine the elements of da'wah by considering cultural aspects related to the elements of da'i, materials, methods, media, mad'u and the dimensions of space and time in the continuity of the interaction of various elements of da'wah; (3) To examine the characteristics of humans, both their positions as da'i and those who become mad'u through a methodological framework in anthropology; (4) To examine the da'wah efforts carried out by each ethnic group; (5) To examine the problems caused by intercultural exchanges and the solution efforts made in order to maintain the existence of their respective cultural identities.

In terms of communication, da'wah material (maddah ad da'wah) is called the message (massage) (Samsul Munir, 2009: 88). Da'wah material is Islamic da'wah messages or everything that must be conveyed by the subject to the object of da'wah, namely the entire Islamic teachings contained in the Book of Allah and the Sunnah of His Messenger. The messages conveyed to the object of da'wah are messages that contain Islamic teachings. Covers the fields of faith, sharia (worship and muamalah) and morals. All of this da'wah material is sourced from the Qur'an, as-Sunnah Rasulullah saw, the results of ijtihad scholars and the history of Islamic civilization (Wahidin Saputra, 2011: 13). The Prophet started da'wah and education through 
mosques or places of worship. The Prophet himself acted as his main educator who was assisted by his closest friends. The main material is the revelation of the Qur'an and hadith, which is complemented by other material as an interpretation of the revelation itself, such as morals (morals), economics, law, art, culture and politics (Moh. Roqib, 2009: 125).

The mosque in terms of etymology comes from the word mosque which is an Arabic vocabulary, namely prayer rug which has the root s-j-d which means prostration or bowing the head until the forehead touches the ground (Ibn Manzhur, 1976: 234). In addition, the word mosque is the root of the original word which is the noun sajdan. Invented words in the form of isim eating are nouns that indicate a place. Thus the mosque is a place of prostration or a place to bow your head to the ground as an expression of full submission to Allah SWT (Asep Usman Ismail \& Cecep Castrawijaya, 2010: 1). The mosque is a holy place for Muslims that functions as a place of worship, a center for religious and social activities that must be fostered, maintained and developed regularly and planned to enliven the symbols of Islam, increase the religious splendor and quality of Muslims in serving Allah SWT, so that responsibility and participation towards the development of the nation will be greater (Syahruddin, et al, 1986: 339).

Apart from being a means of mahdhah worship, the mosque is used as a means of worship for ghairu mahdhah in the form of da'wah, education and others as an alternative with the following considerations: (1) The mosque is the most sterile place from the smell of polytheism and a place that has a high ubudiyah value compared to other places. with other places. The value of worship will be multiplied because seeking knowledge in the Islamic conception is obligatory; (2) The mosque is an open place for various groups without distinguishing elements of race, class, gender and social stratification; (3) Inside the mosque there is a process of integrating faith, knowledge and charity (worship) and also rejecting the dichotomy of science and materialistic attitudes; (4) Able to strengthen the ropes of equality, unity and love among others; (5) Strengthening personality integrity, patience, courage, to speak good and bad deeds (Moh. Roqib, 2009: 143-144).

The role and function of the ghairu mahdhah of the mosque, such as as a place of education, a place for da'wah and Islamic culture, a place for the economic empowerment of the people, a center for cadre of people, where health facilities have not been managed and implemented properly and even there are mosques that have not been able to revitalize the management of mosque management as described above. existed at the time of the Prophet SAW (Hamdi Abdul Karim, 2020). In managing a mosque, what needs to be considered is a harmonious and comfortable interior layout because the mosque is a gathering place for the Muslim community in large numbers. Here, the layout of the mosque takes into account the high architectural art (shape, color, layout and aesthetics). In addition, the mosque has a spiritual moral message that is sacred in terms of its physical building so that it will strengthen the touch of the mosque to its worshipers (Moh. Roqib, 2009: 145).

At first, the mosque was used as a means of preaching Walisongo which then changed and developed for several centuries since the mosque was founded in the Walisongo era until now. Walisongo's da'wah uses a compromise approach to the old culture, so that there is a syncretism between Islamic teachings and Animist, Hindu and Buddhist beliefs. Aspects of change and development of the mosque, one of which is in the architectural form of the Walisongo mosque which can be enjoyed as a result of Walisongo's da'wah which has brought changes in civilization to date (Ashadi, 2013: 1). When Islam began to develop in Indonesia, especially in Java, Islamic architecture was introduced by the saints, as people who were considered close to God and believed to have various advantages. The guardians are tasked with teaching Islam and are very respectful of the culture that developed before the entry of Islam in Indonesia. That's why the saints were highly respected and respected, so that the works of Islamic architecture at that time still showed a mix of old culture and new culture in Islamic architecture.

Later the mosque became a house of worship for a Muslim who also became a religious symbol for Islam. This religious symbol interacts with local culture so that it manifests in the work, creativity, taste, and 
initiative of a combination of religious symbols and the culture of the people. In the terminology of the sociology of religion, Laode Monto Bauto (2014) describes that the acculturation process between Islam and local culture then gave birth to local genius, namely the ability to absorb while conducting active selection and processing of foreign cultural influences, so that a unique new creation can be achieved, which not in the territory of the nation that carries its cultural influence. On the other hand, local genius has characteristics such as: being able to survive against foreign cultures; have the ability to accommodate elements of foreign culture; have the ability to integrate elements of foreign culture into the original culture; and have the ability to control and provide direction for further cultural development.

The context of the Cheng Hoo Purbalingga Mosque is a center for Islamic da'wah that is capable of acculturating culture. Integrating foreign culture with local culture, especially in Purbalingga Regency. This cultural integration does not reduce the essence of the two cultures that are unified, even as a unique identity for the diversity of ethnic Chinese Muslims. The ability to accommodate foreign and local cultures is a cultural force that unites public relations, has a passion for Islamic symbols and penetrates cultural and human boundaries without compromising ethics, morals and noble character.

\section{The Symbolic Da'wah of Cheng Hoo Mosque}

According to the Big Indonesian Dictionary, symbolic means a symbol, becomes a symbol, regarding symbols (Depdiknas, 2007: 703). A symbol or symbol is a kind of sign, painting, saying, badge and so on that states something or contains a specific purpose (Alex Sobur, 2004: 156). Symbol is a symbol which means a sign or feature that tells someone something. Symbols occur based on metonymy, which is the name for other things that are associated or become attributes. Symbols are metaphorical, namely using words or expressions for other objects or concepts based on figures of speech or similarities.

Symbolic meaning is objects, events, speech sounds, or written forms that are given meaning by humans, using signs and symbols in the form of dance, painting, music, architecture and so on (Saifuddin Achmad Fedyani, 2005: 8). Symbolic meaning is a certain meaning or purpose in a word to other objects as symbolic symbols (M. Sastrapradja, 1981: 441). Symbolic meaning is a word, a signifier or a sound object, figure, and the like to describe and describe phenomena such as art, advertising, language, clothing, buildings and what I am which has its own meaning (Marcel Danesi, 2011). The essence of symbolic interaction emphasizes an activity that is characteristic of humans, namely communication or the exchange of symbols that are given meaning (Mulyana, 2010: 68).

Furthermore, Alex Sobur (2004) explains that symbols cannot be treated in isolation, apart from their associative relationships with other symbols. However, unlike sound, symbols already have a unified form and meaning. In contrast to a sign, a symbol is a word or something that can be analogized as a word that is related to (1) user interpretation, (2) usage rules according to the type of discourse, (3) creation of meaning according to the user's intentions. The symbols in and associated with the three items are called symbolic forms.

Based on the narrative of the mosque's founder, Heri Susetyo (Thio Hwa Kong), the establishment of the Cheng Hoo Purbalingga Mosque cannot be separated from the historic event that he became a Chinese convert who initiated and founded the mosque which construction began in 2005. The inspiration for the mosque's establishment was obtained from his religious experience who felt that he had received guidance. to convert to Islam in 2001. After entering and studying Islam for 4 years, he planned to perform the pilgrimage, but the plan was cancelled. The intention to go on a pilgrimage turned into a plan to build a mosque. Together with his colleagues and close people, the plan to build a mosque was realized in 2010 and the mosque building was inaugurated on July 5, 2011.

The symbolic da'wah of the mosque is reflected in the beauty of the Cheng Hoo Mosque. This mosque is a place of worship for all people. The dynamics of the Cheng Hoo Mosque can be described as follows: First, the mosque's architecture resembles a pagoda. This gives a message to the public that Islam is very capable of interacting, adapting, and accommodating the culture of society. That culture has no religion, it becomes a 
symbol for anyone, including an identity for religious people (Islam). The impression that appears on the mosque's architecture resembles a temple building. The pagoda which is a symbol of China is the main ornament of the mosque building.

Second, building ornaments that use interior and exterior designs in Chinese culture. Stained glass ornaments that look elegant and charming, striking octagonal shapes (pat kwa) on the roof and stained glass vents, and mosque light sources decorated with colorful geometric shapes (https://www.aroengbinang.com, 2021). In addition, there is a drum that is hung on the side of the mosque, as the cultural identity of Javanese mosques in general. The stacked chandelier looks beautiful in the main room of the mosque with an octagonal ceiling that reads Arabic saying Allah. Then on the mihrab of the mosque there is an ornament in the form of an eight-pointed star on the ceiling that surrounds the ornament of a rectangular box which is equipped on the front with a line of text from the holy Qur'an. Third, this mosque is very open (inclusive) for any Muslim from various sects and religious groups. The shape of the mosque, which can be considered rare, indicates that the Cheng Hoo mosque is very open to culture. In other words, Islam is very accepting and accommodating of any culture, as long as it does not conflict with the values of Islamic law. According to Heri Susetyo, this mosque was established for the purposes of worshiping Muslims as a whole. Cheng Hoo Mosque is not affiliated with any particular religious group or organization, but the existence of a mosque for all circles. Indeed, in terms of management, the Cheng Hoo mosque is under the guidance of the Indonesian Chinese Islamic Association (PITI) in Purbalingga Regency, but it does not side with any particular religious organization or even a particular political party. This is what makes the Cheng Hoo mosque able to accept all groups and can be accepted by various religious backgrounds in a pluralistic society.

Fourth, the mosque as a da'wah space for the community. Apart from being a place of worship, the mosque is used for Islamic da'wah activities. These activities are carried out according to the needs of the community, especially on the commemoration of Islamic holidays. The founder of the mosque, Heri Susetyo, said that the da'wah presented in mosque activities was delivered peacefully and inclusively. So that the chosen preachers and lecturers are those who have qualified scientific capacity, morality, and respect for differences (diversity). The message of da'wah conveyed was to foster the unity of the people, this is in line with the PITI platform as a religious organization that loves unity and brotherhood. The da'wah that is developed is the da'wah of rahmatan lil alamin, the da'wah that is full of friendliness not anger, the da'wah that is full of invitations for goodness not ridicule of evil.

Fifth, the mosque is a place for the economic development of the people. One of the highlights of the mosque is that there is a spot rest area for visitors and road users. This spot rest area has been developed into a food court or culinary and hawker center that provides fast food. This food court area has an economic impact on mosques, organizations, and the surrounding community. The traders in the food court are residents of Selaganggeng Village, Mrebet District and its surroundings. Food court activities bring economic income to the community, so in this connection the mosque has the function of driving the economic empowerment of the people who are prosperous. Through the economic empowerment of the people, the mosque contributes to the surrounding community who have benefited and prospered.

\section{Arab, Javanese, and Chinese Cultural Acculturation}

Acculturation is a word that comes from English, namely, acculturate which has the meaning of adapting (to new cultural customs or foreign habits) (Shadily, 1976: 7). In the Big Indonesian Dictionary, acculturation is a mixture of two or more cultures that meet and influence each other or the process of entering foreign cultural influences into a society, some selectively absorbing a little or a lot of elements of that foreign culture. The entry of Islam into the archipelago (Indonesia) and in subsequent developments there has been a cultural interaction that influences each other. However, in the process of interaction, the traditional local culture is still strong, so that there is a blend of Indonesian native (local) culture with Islamic culture. This combination is then called cultural acculturation. Acculturation is a social process that arises when a human group with a certain culture is confronted with elements of a foreign culture in such a way that the elements 
of a foreign culture can gradually be accepted and processed into their own culture without causing the loss of the culture itself.

The combination of elements of the old culture with the new culture in Islamic architecture, has shown the existence of acculturation in the process of realizing Islamic architecture, especially in Java. Moreover, at the beginning of the development of Islam in Java, it was carried out with a selective process without violence, so that some of the old values were still accepted to be developed. After the Majapahit empire collapsed, a new era of the Islamic kingdom began to emerge on the archipelago. The teachings of Islam that enter without violence are open to elements of the existing old culture. That's why the form of Islamic architecture, especially mosque architecture in Indonesia, is heavily influenced by historical factors, regional cultural background, environmental factors and the customs of the local community (Wiryo Prawiro, 1986).

Before Islam entered and developed, Indonesia already had a cultural style that was influenced by Hinduism and Buddhism. With the entry of Islam, Indonesia again experienced a process of acculturation (the process of mixing two (more) cultures due to the mixing of nations and mutual influence), which gave birth to a new culture, namely Indonesian Islamic culture. The entry of Islam does not mean that Hindu and Buddhist cultures are lost. Islamic teachings began to enter Indonesia around the century (VIII / XI / XV). The early spread of Islam in the archipelago was carried out by Arab, Chinese, Indian and Persian traders. After that, the process of spreading Islam was carried out by the Islamic archipelago kingdoms through marriage, trade and war (Uka Candra Sasmita, 2000).

Many mosques that are exalted in Indonesia still maintain their original shape that resembles (for example) Hindu/Buddhist temples and even East Asian pagodas, or also use construction and ornamentation of buildings typical of the area where the mosque is located. In subsequent developments, mosque architecture adopted more forms from the Middle East, such as the onion dome roof and ornaments, which were introduced by the Dutch East Indies Government (www.wisatamelayu.com, Sunday, June 08 2015).

When viewed from the time of its construction, the mosque was greatly influenced by the culture that entered the area. The old mosque, especially in the area of the island of Java, has a shape that is almost the same as a Hindu-Buddhist temple. This is because there is cultural acculturation between local cultures and foreign cultures. Between one region with another usually there are also differences in shape. This is also influenced by environmental conditions and local culture (Tawalinudin Haris, 2008).

The entry of Islam to Java, in the context of culture, had an impact on the acculturation of Islam and Javanese culture, namely the culture that had lived and developed during the heyday of the Javanese Hindu kingdoms. Acculturation of Islam and Javanese culture can be seen in tombstones, architecture (art of building), literary arts, carving arts, and various traditions of celebrating Islamic holidays. Acculturation of Islam and Javanese culture can be seen in every era of the sultanate (Islamic kingdom) in Java, both the Demak era, the Pajang era, and the Islamic Mataram era. In the Demak era, acculturation between Islam and Javanese culture occurred in many ways, for example, architecture, carving, wayang art, funeral patterns, and literary arts (such as chronicles, saga, and others). Various results of acculturation of Islam and Javanese culture are used as a means for inculcating Islamic values into Javanese society (Donny Khoirul Azis, 2013).

The form of culture as a result of the acculturation process is not only material, but also involves the behavior of the Indonesian people. The form of acculturation in building art can be seen in mosques, tombs and palaces. Like the architecture of the Muhammad Cheng Hoo Indonesia Mosque in Surabaya, it comes in an architecture that has a Chinese nuance. A new architectural form for a mosque in Indonesia as well as an appearance of architectural forms that have long been lost in Indonesian architectural treasures. A form that is also present as a blend of various interesting local elements. This architectural expression is an expression of the spirit of tolerance which is always able to adapt to its new environment, such as the attitude of life of Chinese ethnic ancestors. The main thing is the example and attitude of Admiral Cheng Hoo, who is cosmopolitan and always lives in harmony with his new environment (Freddy H. Istanto, 2003). 
The name Muhammad Cheng Hoo Purbalingga Mosque was inspired by the name of Admiral Cheng Hoo, an admiral who led a famous large shipping fleet. He is a warlord who comes from Yunnan and is Muslim. Admiral Cheng Hoo often made voyages to various regions, including to the Southeast Asia region and had also carved a shipping trail in the archipelago. In historical records, Admiral Cheng Hoo never stopped at Purbalingga, Central Java, but the name was used as the name of a mosque with Chinese architecture.

The mosque measuring 11 x 9 square meters is located on Jalan Raya Selaganggeng Village, Mrebet District. The distance from the center of the city of Purbalingga is about $12 \mathrm{~km}$ to the north towards the city of Bobotsari District. This mosque is a form of acculturation of Chinese and Javanese architecture. At first glance, this mosque looks like a temple. There is no round dome on the roof of the mosque like most Muslim places of worship. The dome of this mosque is in the form of an octagonal pagoda that is tiered. Each side and level bulged out like a dragon's tail.

Red and yellow colors dominate the entire Cheng Hoo mosque, similar to the color of temples in various regions in Indonesia. In addition to the colors that highlight the characteristics of Chinese architecture, the Cheng Hoo mosque is also decorated by several Chinese lanterns which are also red and yellow. In addition, the pillars of the mosque outside are also red. Meanwhile, the windows are octagonal in shape with red and yellow edges.

At the main entrance, there is a golden yellow kanji written on a black board. Meanwhile on the left side of the building there is a red drum, a color that is rarely used on drums in other mosques in Indonesia. The ceiling of the main room of the Cheng Hoo Purbalingga Mosque is decorated with a hanging chandelier in the middle. On each octagonal plane of the ceiling there is an Arabic inscription that reads "Allah". The writings were made by pulling straight lines so that they barely resembled Arabic letters.

The architecture of the Cheng Hoo mosque was inspired by the Niu Jie Mosque (Ox Street) in Beijing which was built in 996 AD. The style of the Niu Jie mosque can be seen on the top, main roof, and crown of the mosque. The rest, the result of the combination of Middle Eastern architecture and local Javanese culture, became the inspiration for the shape of this mosque. On the north side of the mosque there is a relief of Muhammad Cheng Hoo and the fleet of ships he used to navigate the Indian Ocean. This relief has a message to Chinese Muslims in Indonesia in particular not to feel uncomfortable and arrogant as Muslims. Chinese people practicing Islam is not a strange or extraordinary thing.

The architecture of the building which is unique, interesting, and similar to a pagoda building that resembles a temple as a place of worship for the Confucians has become a distinct feature in Islamic treasures. Cheng Hoo Purbalingga Mosque has an attractiveness, from the outside, it doesn't really look like a mosque building, but when you go inside, the nuances of Islam will be clearly visible as the mingling of acculturation of Chinese culture with Islam is clear.

As a norm, rule, as well as all activities of Indonesian society, Islamic teachings have become a pattern for the community. In this context, Islam as a religion has also become a culture of Indonesian society. On the other hand, local cultures that exist in society do not automatically disappear with the presence of Islam. Some of these local cultures continue to be developed by getting Islamic colors. This development then gave birth to "cultural acculturation", between local culture and Islam (Laode Monto Bauto, 2014).

Based on the narrative of the founder of the Cheng Hoo Mosque, Heri Susetyo (Thio Hwa Kong), that the shape of the mosque is the result of a combination of Arabic, Javanese and Chinese (Arwana) mosque architectural styles. The combination of arowana is a form of cultural acculturation that symbolizes the harmonization of cultural and religious life. This acculturation implies an intimate relationship between cultural entities that collaborate with each other in mutualism. This arowana collaboration is a symbol of unity in open diversity regardless of the location of differences. Cheng Hoo Mosque was built on the willingness and openness of which later took shelter under the coordination of the Indonesian Chinese Islamic Association (PITI) Purbalingga Regency. This mosque is a missionary identity of its own which will not only be a symbol of Muslims but also a destination for the rich potential of the Purbalingga Regency. 
The mosque building has undergone many transformations and has been influenced by various cultures. Islam is increasingly in contact with other cultures, so that it not only affects Islam in the values of its religious teachings, but also affects architecture in Islam itself.

\section{Symbolic Da'wah Value}

In a very diverse association, common rules are needed to build unity in diversity, Kuntowijoyo calls it positive pluralism. Common rules in interreligious relations are needed, so that there is no relationship based on prejudice. Positive pluralism will be put forward as a rule including: (1) Besides religion itself, there are other religions that must be respected (pluralism), and (2) Each religion must continue to uphold its religion (positive). Pluralism becomes negative when people think of religion as clothes, they can change things. As if changing religion is not a big problem, if it is done in the name of nationalism, in the name of democracy, in the name of human rights or in the name of another (Kuntowijoyo, 2018: 203-204).

According to Turner (1987), the theory of social harmony sees at least 5 (five) things that make harmony and balance in social harmony possible. The five things are: a) the value of whether the values held by one group contradict or not with another, b) idealism whether the goals to be achieved are contradictory or not, c) the structure of whether the social structure is unequal and social institutions function properly or not, d) reciprocity whether there is a mutually beneficial or even detrimental relationship, e) interaction whether the interaction runs normally or there is a blockage between groups.

Symbolically, the ornaments and architectural forms of the Cheng Hoo Mosque contain the value of da'wah. The content of symbolic da'wah values contained, namely: the value of beauty (artistic), cultural value (turats), accommodative value, brotherhood value (ukhuwah), the value of unity, and the value of diversity.

First, the value of beauty (artistic). Cheng Hoo Mosque has become an object that contains beauty because of its unique physical form, ornamentation, interior, and exterior, and is of interest to the public. Beauty becomes a form of value that many people seek in the desired subject. Especially for public places such as houses of worship, a beautiful atmosphere will add comfort and tranquility in worship. Building a beautiful mosque is not the goal, but providing comfort for mosque visitors is the main target in mosque construction. So the presence of the Cheng Hoo mosque which has this unique ornament brings an interesting impression (interest) for the public to visit it. As long as beauty brings blessings, especially

Second, cultural values (turats). Cheng Hoo Mosque necessitates a harmonious blend of cultures. Culture is a medium for dynamizing the closeness of religion and community culture. Religion and culture are embedded in polite and wise local wisdom. Culture as a medium to integrate different types of entities in the name of the unity of the people. Cultural acculturation depicted in the arowana collaboration shows cultural values that continue to be cared for as a way of unifying the people. The combination of cultures that gives color and religious style to the plurality of society.

Third, accommodative value. The ability of Islam to accommodate various cultures with various variations, proves that Islam is a religion that is rahmatan lil alamin. Religion that is able to spread love to all mankind and even the universe. This ability to accommodate is manifested in the pattern of interaction between Islam and local culture that greets each other. This means that the accommodative value in Islam negates modesty and tolerance between religions and cultures. So that both of them can bring out the benefits of mutualism symbiosis as long as they do not violate the provisions of Islamic law.

Fourth, the value of brotherhood (ukhuwah). Cheng Hoo Mosque carries the value of brotherhood, this can be extracted from the mosque's symbol describing collaborative cultural interactions between Arabic, Javanese and Chinese. Intercultures collaborate and unite in human brotherhood through cultural media. In addition, socially, the mosque can get along with the surrounding community, even though it is led by people of Chinese descent, but brotherhood with the Javanese Ngapak Purbalingga, to be precise, in Selanganggeng Village, Mrebet District and its surroundings can be harmoniously established. 
Fifth, the value of unity. The unification of cultural entities in harmonization in the midst of a plural society is a symbol of the importance of the value of the unity of the people. The value of unity symbolizes cultural differences that are constructed in mosque architecture through cultural acculturation within the framework of the Islamic religion. Unity in diversity describes a beautiful rainbow built on charming colorful differences. So that through this unity we can build a more important ummah mission, including empowering the people's economy, social generosity, and mutual cooperation.

Sixth, the value of diversity. The collaborative diversity of arowana acculturation negates the power of peace in diversity. Plural society is not an obstacle to be able to complement each other. Living in diversity has become sunatullah, it is only the efforts of the people to be able to manage this diversity to become the strength of the people to create peace, harmony, and national unity, so as to create baldatun thayyibatun warabbun ghafur.

\section{Message (Wisdom) Symbolic Da'wah}

The establishment of the Cheng Hoo Mosque gives a message (wisdom) of da'wah that Islam teaches friendliness and openness to all cultural entities in society, Islam adapts and interacts with various community traditions and Islam teaches tolerance in a life full of diversity. The birth of an increasingly complex religious attitude among the people, demands the presence of da'wah that upholds the value of diversity.

In this context, the da'wah material delivered by the preacher or preacher at the Cheng Hoo Mosque can provide understanding for the people in being more moderate in religion. Symbolic da'wah is displayed as a medium to provide religious maturity through mosque symbols that resemble pagodas or temples. So it is hoped that these two things will provide collective awareness that intertwines ukhuwah Islamiyah, ukhuwah basyariyah and ukhuwah wathaniyah as the message of Islam rahmatan lil alamin to create a more moderate society in religion. The message (wisdom) of the Da'wah of the Cheng Hoo Mosque hints at a peaceful and harmonious life in religious and cultural differences. A harmonious life is the noble ideal of human nature.

\section{Conclusion}

Muhammad Cheng Hoo Mosque Purbalingga is a center for Islamic da'wah that is capable of acculturating culture. Integrating Chinese culture with local culture, especially in Purbalingga Regency. The cultural integration does not reduce the essence of the two cultures which are the unique identities of the ethnic Chinese Muslims in carrying out their da'wah missions. The ability to accommodate this culture becomes the cultural strength of the people in Islamic symbols that penetrates the barriers of culture and humanity. The result of this cultural acculturation is a blend of Arabic, Javanese and Chinese (Arwana) mosque architectural styles. The combination of arowana is a form of cultural acculturation that symbolizes harmonization, collaboration and mutualism in cultural and religious life. The dynamics of symbolic da'wah is described in the architectural form of the mosque which resembles a pagoda which is better known as the Temple. Building ornaments with interior and exterior designs in Chinese culture. The mosque is an inclusive space for Muslims from various sects and religious groups. As a space for Islamic da'wah for the community, and a means of empowering and developing the people's economy. The content of symbolic da'wah values contained, including the value of beauty (artistic), cultural value (turats), accommodative value, brotherhood value (ukhuwah), the value of unity, and the value of diversity. Symbolic da'wah through cultural acculturation has become an Islamic style that is able to integrate religion and culture that strengthens unity and harmonization in life.

\section{Reference}

1. Abdul Jamil, dkk. (2015). Pelangi Agama di Ufuk Indonesia, Fakta dan Cerita Kerukunan Beragama, Jakarta: Pusat Kerukunan Umat Beragama Kementerian Agama RI.

2. Afriani, D. W. (2014). Masjid Jami PITI Laksamana Muhammad Cheng Ho Purbalingga: Simbol Keindahan Toleransi Dalam Akulturasi. IBDA: Jurnal Kajian Islam dan Budaya, 12(1), 27-39. 
3. Al-Amri, L., \& Haramain, M. (2017). Akulturasi Islam Dalam Budaya Lokal. KURIOSITAS: Media Komunikasi Sosial dan Keagamaan, 10(2), 87-100. https://doi.org/10.35905/kur.v10i2.594.

4. Amin, Kamaruddin. (2019). Halaqah Pengembangan Pendidikan Islam (HAPPI) 2019, Jakarta: Direktur Jenderal Pendidikan Islam.

5. Anwar, C. (2018). Islam Dan Kebhinekaan Di Indonesia: Peran Agama Dalam Merawat Perbedaan. Zawiyah: Jurnal Pemikiran Islam, 4(2), 1-18. http://dx.doi.org/10.31332/zjpi.v4i2.1074.

6. Apriyanto, A. (2017). Ideologi Masjid Cheng Hoo di Bobotsari. Jurnal Ilmiah Mahasiswa Raushan Fikr, 6(1), 83-90.

7. Arif, Syaiful. (2010). Deradikalisasi Islam Paradigma dan Strategi Islam Kultural, Depok: Penerbit Koekoesan.

8. Atika, A. (2020). Makna Simbolik Arsitektur Masjid Agung Sang Cipta Rasa sebagai Media Dakwah pada Masyarakat Cirebon (Analisis Semiotika Charles Sanders Peirce) (Skripsi, IAIN Purwokerto).

9. Azis, D. K. (2013). Akulturasi islam dan budaya jawa. fikrah, 1(2). http://dx.doi.org/10.21043/fikrah.v1i2.543.

10. Damayanti, R., Triyanto, T., \& Syarif, M. I. (2016). Masjid Jami’ PITI Muhammad Cheng Hoo Purbalingga: Refleksi Akulturasi Budaya pada Masyarakat Purbalingga. Catharsis, 5(2), 99-106.

11. Depdiknas, (2007). Kamus Besar Bahasa Indonesia, Edisi Ketiga, Jakarta: Balai Pustaka.

12. Fahri, M., \& Zainuri, A. (2020). Moderasi Beragama di Indonesia. Intizar, 25(2), 95-100.

13. Fasya, F. (2018). Dakwah simbolik pada kaos Izma Muslim (Skripsi, UIN Sunan Gunung Djati Bandung).

14. Haris, Tawalinudin. (2008). Masjid-masjid di Dunia Melayu Nusantara, Diktat Perkuliahan UI.

15. https://kabar24.bisnis.com/read/20190311/79/898454/kemenag-susun-buku-putih-moderasi-beragama, diakses 11 Maret 2020.

16. https://tirto.id/15-masjid-yang-mengabadikan-cheng-ho-di-indonesia-cpDS, 17 November 2021.

17. http://www.wisatamelayu.com, (Minggu, 08 Juni 2015)

18. Ismail, Asep Usman \& Castrawijaya, Cecep. (2010). Manajemen Masjid, Bandung: Angkasa.

19. Istanto, F. H. (2003). Semangat admiral Cheng Hoo dan ekspresi toleransi Masjid Muhammad Cheng Hoo Indonesia. DIMENSI (Journal of Architecture and Built Environment),31(1). https://doi.org/10.9744/dimensi.31.1.

20. Jhon M. Echols dan Hasan Shadily. (1976). Kamus Inggris Indonesia, Jakarta: PT. Gramedia Pustaka Utama.

21. Karim, H. A. (2020). Revitalisasi Manajemen Pengelolaan Peran Dan Fungsi Masjid Sebagai Lembaga Keislaman. Jurnal Isema: Islamic Educational Management, 5(2), 139-150. https://doi.org/10.15575/isema.v5i2.9464.

22. Kuntowijoyo. (2006). Budaya dan Masyarakat, Edisi Paripurna, Yogyakarta: Tiara Wacana.

23. . (2018). Identitas Politik Umat Islam, Yogyakarta: IRCiSoD.

24. Mahfud, C. (2018). Chinese Muslim Community Development in Contemporary Indonesia: Experiences of PITI in East Java. Studia Islamika, 25(3), 471-502. https://doi.org/10.15408/sdi.v25i3.6755.

25. Manzhur, Ibnu. (1976). Lisan al-Arab, Bairut: Dar al-Fikr.

26. Marcel Danesi, (2011). Pesan Tanda dan Makna (Buku Teks Dasar Mengenal Semiotika dan Teori Komunikasi), Yogyakarta: Jala Sutra.

27. Marthia, F. F. (2018). Akulturasi Budaya Pada Arsitektur Masjid Jami PITI Muhammad Cheng Hoo Purbalingga.

28. Muhammad, M. F. (2020). Sejarah dan Makna Arsitektur Masjid Jam'i PITI Muhammad Cheng Hoo Selaganggeng Mrebet Purbalingga (2005-2011) (Sripsi, IAIN Purwokerto).

29. Mulyana, Deddy, (2010). Komunikasi Lintas Budaya. Bandung: Remaja Rosda Karya.

30. Munir, Samsul. (2009). Ilmu Dakwah, Jakarta: Amzah.

31. Panuntun, I. R. B. (2018). Bentuk dan Makna Pada Ragam Hias Masjid Jami’ PITI Muhammad Cheng Hoo Purbalingga. Pendidikan Seni Kerajinan-S1 (e-Craft), 7(2), 171-185.

32. Prasanti, D., \& Indriani, S. S. (2017). Pemaknaan Simbol dalam Komunitas 'Brotherhood' (Konstruksi Makna Simbol Sebagai Identitas Diri dalam Komunitas 'Brotherhood' di Bandung). Semiotika: Jurnal Komunikasi, 10(1). http://dx.doi.org/10.30813/s:jk.v10i1.25.

33. Romadlan, S. (2019). Toleransi Terhadap Non-Muslim Dalam Pemahaman Organisasi Islam Muhammadiyah dan Nahdlatul Ulama (NU). Journal of islamic Comunication, 1(2). 10.21111/sjic.v1i2.2740.

34. Roqib, Moh. (2009). Ilmu Pendidikan Islam, Yogyakarta: LkiS.

35. Salim, Hairus dan Suhadi. (2009). Membangun Pluralisme dari Bawah, Modul Belajar Bersama Anak Muda Multikultural, Yogyakarta: LKiS. 
36. Saifuddin Achmad Fedyani, (2005). Antropologi Kontemporer. Jakarta: Kencana.

37. Saputra, Wahidin. (2011). Pengantar Ilmu Dakwah, Jakarta: PT. RajaGrafindo Persada.

38. Saputri, V. S. D. (2017). Dominasi Arsitektur Tionghoa Masjid Cheng Hoo. Jurnal Ilmiah Mahasiswa Raushan Fikr, 6(1), 1-9. https://doi.org/10.24090/jimrf.v6i1.2707

39. Sastrapradja, M. (1981). Kamus Istilah Pendidikan dan Umum (untuk Guru, Calon Guru dan Umum), Surabaya: Usaha Nasional.

40. Sumardiana, B. (2017). Efektifitas Penanggulangan Ancaman Penyebaran Paham Ekstrim Kanan yang Memicu Terorisme oleh POLRI dan BNPT RI. Law research review quarterly, 3(2), 109-128. https://doi.org/10.15294/snh.v3i1.20927.

41. Sulthon. (2003). Menjawab Tantangan Zaman Desain Ilmu Dakwah Kajian Ontologis, Epistemologis, dan Aksiologis, Cet. I, Yogyakarta: Pustaka Peiajar.

42. Supardjo, U. (2011). Sekilas Sejarah Berdirinya Masjid Jami PITI Muhammad Cheng Hoo Kabupaten Purbalingga. Purbalingga: DPC PITI Kabupaten Purbalingga.

43. Susanti, A. Y. (2017). Sejarah dan Arsitektur Masjid Jami PITI Muhammad Cheng Ho di Desa Selaganggeng (2005-2016) (Skripsi, Universitas Muhammadiyah Purwokerto).

44. Syahid, M. P. Islam dalam Budaya \& Budaya Dalam Islam. (2019). https://www.academia.edu/45677573/Selayang_Pandang_Islam_dalam_Budaya_dan_Budaya_dalam_Islam?a uto=citations\&from=cover_page.

45. Syahruddin, dkk. (1986). Mimbar Masjid, Jakarta: CV. Haji Masagung.

46. Sobur, Alex. (2004). Semiotika Komunikasi, Bandung: PT. Remaja Rosdakarya.

47. Uka Candra Sasmita, (2000). Pertumbuhan dan Perkembangan Kota-kota Muslim di Indonesia, dari Abad XIIIXVIII Masehi, Kudus: Menara Kudus.

48. Wardani, M. D. (2019). Makna Simbolik Infrastruktur Trotoar (Studi Perspektif Dakwah Pembangunan di Kota Salatiga) (Skripsi, IAIN Salatiga).

49. Wiryo Prawiro, (1986). Perkembangan Arsitektur Masjid di Jawa Timur, Surabaya: Bina Ilmu.

50. Wulandari, E. (2016). Kajian Ikonografi Arsitektur dan Interior Masjid Cheng Hoo Purbalingga (Tesis, Pascasarjana ISI Yogyakarta).

51. Yunus, A. F. (2017). Radikalisme, Liberalisme dan Terorisme: Pengaruhnya Terhadap Agama Islam. Jurnal Studi Al-Qur'an, 13(1), 76-94. https://doi.org/10.21009/JSQ.013.1.06.

52. Zarnia, A. N. (2019). Peran Masjid Jami PITI Muhammad Cheng Ho di Desa Selaganggeng Kecamatan Mrebet Kabupaten Purbalingga (Skripsi, IAIN Purwokerto). 